\title{
Optimal Oxygen Saturation in Extremely Premature Neonates
}

\section{P. ZOBAN}

Division of Neonatology, Department of Obstetrics and Gynecology, Second Faculty of Medicine, Charles University and Motol University Hospital, Prague, Czech Republic

Received July 20, 2018

Accepted September 25, 2018

Epub Ahead of Print January 10, 2019

\section{Summary}

So far, great efforts have been made to understand the demands of extremely premature neonates (EPNs'; born before the $28^{\text {th }}$ week of gestation) on postnatal care, including optimal oxygen saturation, that will allow them to survive without disability. A major yet unresolved problem is to find an "optimal range" of their oxygen saturation and to maintain it without drops or increases, i.e., without hypoxia or hyperoxia. The individual sections of this paper deal with the changes of $\mathrm{SpO}_{2}$ (an estimate of $\mathrm{SaO}_{2}$ measured by pulse oximetry) that occur before, during, and after premature labor, postnatal factors affecting $\mathrm{SpO}_{2}$, and especially how to find an acceptable compromise in choosing the most effective and minimally harmful range of $\mathrm{SpO}_{2}$ for $\mathrm{EPNs}^{\prime}$ with the careful $\mathrm{FiO}_{2}$ adjustment and continually monitored $\mathrm{SpO}_{2}$. At present, the two $\mathrm{SpO}_{2}$ ranges, narrow (90-94 \%) vs. wider (88-94\%), are most discussed. However, the question of how much oxygen is too much or little remains unanswered. There is even a view that there is no uniform optimal $\mathrm{SpO}_{2}$ range for EPNs, and that each newborn has its own, individually specific range that changes due to its intrinsic and/or extrinsic factors.

\section{Key words}

Prematurity • Extremely premature neonate - Oxygen therapy • Oxygen saturation $\bullet$ Target range of $\mathrm{SpO}_{2}$

\section{Corresponding author}

Petr Zoban, Kremnicka 3030/9, 14100 Prague 4, Czech Republic. E-mail: Petr.Zoban@fnmotol.cz

\section{Introduction}

Extremely prematurity remains a global health problem. Despite an increasing amount of knowledge in neonatology and technological advances during last two decades, the extremely premature neonates (EPNs') (below 28 weeks' gestation) remain at high risk for death and disability with 30-50\% mortality and, in survivors, at least $20-50 \%$ of morbidity (Glass et al. 2015).

The conclusions of five large clinical trials from 2010-2016, comparing the effectiveness and safety of the higher (91-95\%) vs. lower (85-89\%) oxygen saturation range in EPNs', supported the higher oxygen saturation range due to lower institutional mortality despite an increased incidence of retinopathy of prematurity (ROP). However, the question of what is the optimal oxygen saturation for EPNs' remains still open. Discussions on this topic are continuing with periodically changing intensity without a final consensus being reached.

This review provides a summary of the current findings and opinions on how to provide an effective and safe oxygen treatment in the EPNs'.

\section{Brief history of oxygen therapy in premature infants}

In 1940-50, the liberal administration of oxygen to the preterm newborn infants caused literally an epidemic of retrolental fibroplasia (RLF) (Terry 1942, Campbell 1951, Cross 1951), today called as retinopathy of prematurity (ROP). The restriction in oxygen administration in the 1960-70 has brought the reduction of incidence of retinal damage, but mortality due to hypoxia and the number of premature infants affected 
by hypoxia have risen again.

Searching for the optimal markers of the oxygenation and their values in preterm neonates, indicating the risk of hypoxemia or hyperoxemia continues with the same intensity to this day. In 2007, the American Academy of Pediatrics (AAP) proposed to maintain oxygen saturation measured by pulse oximetry $\left(\mathrm{SpO}_{2}\right)$ within the pragmatically derived range of 85-95\%, and partial pressure of oxygen in arterial blood $\left(\mathrm{PaO}_{2}\right)$ between $50-80 \mathrm{mmHg}$ (American Academy of Pediatrics, American College of Obstetricians and Gynecologists 2007). The European guideline of 2007 recommended maintaining $\mathrm{SpO}_{2}$ below $95 \%$, but the lower limit was not defined (Sweet et al. 2007). The latest version of European guideline for the administration of oxygen in the premature neonates, even extremely premature, recommends maintaining $\mathrm{SpO}_{2}$ between 90-94\% (Sweet et al. 2017).

\section{Factors related to oxygenation}

The key factors of neonatal oxygenation are effective breathing (ie. central control of breathing and the lung maturity), ventilation/perfusion ratio, partial pressure of oxygen $\left(\mathrm{PO}_{2}\right)$, cardiac output (CO), hemoglobin $(\mathrm{Hb})$ concentration, and homeostasis of internal environment.

Oxygen capacity is the maximum quantity of oxygen that can be bound to each gram of $\mathrm{Hb}$ (i.e., $1.34 \mathrm{ml} \times \mathrm{Hb}$ level in gram). The number derived from this equation indicates the total oxygen-carrying capacity of $\mathrm{Hb}$ in a particular neonate.

Oxygen saturation means the oxygen content expressed as a percentage of oxygen capacity. Oxygen saturation tells how much oxygen is carried only if the amount of $\mathrm{Hb}$ is known (Glickstein 2007). About $97 \%$ of oxygen is bound to hemoglobin while $3 \%$ is dissolved in the plasma.

Oxygen hemoglobin dissociation curve shows the different ability of fetal $\mathrm{Hb}(\mathrm{HbF})$ and adult $\mathrm{Hb}$ ( $\mathrm{HbA}$ ) to bind oxygen (Fig. 1). The curve for $\mathrm{HbF}$ is said to be shifted to the left of the $\mathrm{HbA}$ curve, representing the greater affinity of $\mathrm{HbF}$ for oxygen at any given $\mathrm{PO}_{2}$. This results in less of an ability of $\mathrm{HbF}$ to release oxygen to the tissues. Factors that shift $\mathrm{Hb}$ dissociation curve to the right (and thereby increase oxygen delivery to tissues) include increased body temperature, $\mathrm{PCO}_{2}$, 2, 3-diphosphoglycerate (2, 3-DPG) content in erythrocytes, and decreased pH (Glickstein 2007, Cummings and Polin 2016).
Relationship between $\mathrm{SaO}_{2}$ and $\mathrm{PaO}_{2}$ is reasonably linear at $\mathrm{SaO}_{2}$ values $<80 \%$, but the slope of that relationship changes at $\mathrm{SaO}_{2}$ levels $>80 \%$, resulting in large changes in $\mathrm{PaO}_{2}$ with small changes in $\mathrm{SaO}_{2}$. This relationship is even more exaggerated in the presence of $\mathrm{HbF}$ with the $\mathrm{HbO}_{2}$ dissociation curve shifted to the left. Given that $\mathrm{SpO}_{2}$ (i.e. oxygen saturation measured by pulse oximetry) measurements become poor predictors of actual $\mathrm{PaO}_{2}$, particularly when the infant is receiving supplemental oxygen, it is still necessary to monitor both $\mathrm{SpO}_{2} / \mathrm{SaO}_{2}$ and $\mathrm{PaO}_{2}$, especially when $\mathrm{SpO}_{2}$ reaches the high limit values (Saugstad 2016, Cummings and Polin 2016).

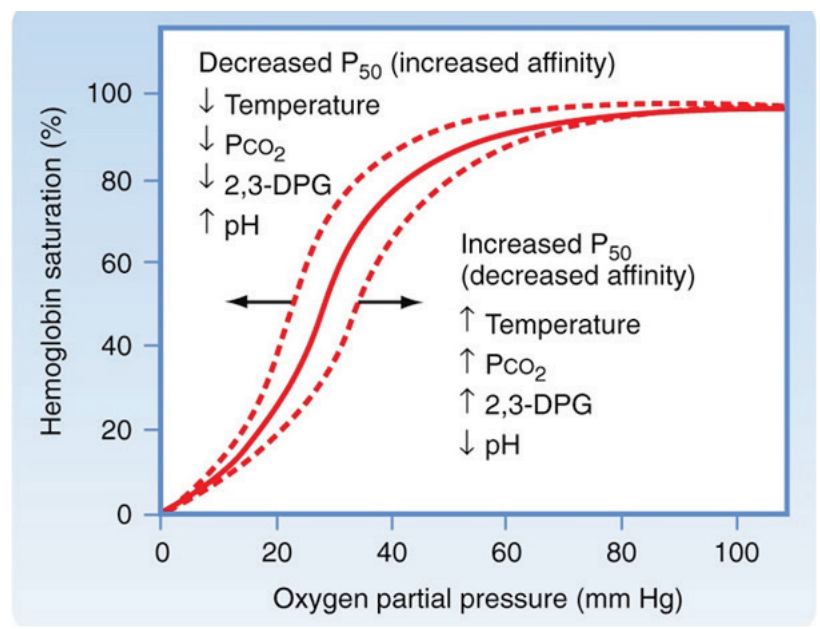

Fig. 1. Oxygen-hemoglobin dissociation curve and relationship between $\mathrm{SaO}_{2}$ and $\mathrm{PaO}_{2}$

The curve for fetal hemoglobin is shifted to the left of the adult hemoglobin curve which means a higher affinity of fetal hemoglobin for oxygen and less ability to release oxygen to the tissues. $\mathrm{SaO}_{2} / \mathrm{PaO}_{2}$ relationship is reasonable linear at $\mathrm{SaO}_{2}$ values up to $80 \%$ (see blue arrow), but at $\mathrm{SaO}_{2}$ of $80 \%$ and above, the relationship becomes asymptotic and provides inaccurate estimate of $\mathrm{PaO}_{2}$. Because the $\mathrm{SaO}_{2}$ and $\mathrm{SpO}_{2}$ values are not very different, $\mathrm{SpO}_{2}$ measured by pulse oximetry will also be inaccurate for the $\mathrm{PaO}_{2}$ estimate.

\section{Monitoring of oxygen saturation}

Current "bed-side" methods monitoring neonatal oxygenation are both invasive and noninvasive (based on transcutaneous technique of measurement).

Invasive monitoring of $\mathrm{PaO}_{2}$ and $\mathrm{SaO}_{2}$ is associated with repeated sampling of arterial blood. The length of such monitoring and frequency of blood sampling is determined by the newborn's clinical condition and availability of arterial access.

Noninvasive oxygen monitoring is based on two technologies, the transcutaneous $\mathrm{PO}_{2}$ measurement and pulse oximetry. 
Transcutaneous $\mathrm{PO}_{2}$ measurement $\left(t c \mathrm{PO}_{2}\right)$ - the method uses a Clark-type sensor that is applied tightly to the skin. The sensor is heated to $43-44{ }^{\circ} \mathrm{C}$ to produce local hyperemia, which maximizes capillary blood flow under the sensor. Tissue oxygen then diffuses across the epidermis to the sensor membrane, where it is chemically reduced, producing a current proportional to the $\mathrm{PaO}_{2}$. After sensor replacement, a 10 to $15 \mathrm{~min}$ of equilibration is needed than relevant readings will be available. Under optimal steady-state conditions, correlation with $\mathrm{PaO}_{2}$ is 0.90 to 0.95 (Richardson and Eichenwald 1998).

The pulse oximetry and $\mathrm{SpO}_{2}$ measurement is the most commonly used non-invasive method measuring oxygen saturation of the fetus or neonate $\left(\mathrm{FpO}_{2} / \mathrm{SpO}_{2}\right)$. This technology is based on a different absorption of infrared light by oxygenated or deoxygenated hemoglobin $\left(\mathrm{HbO}_{2}, \mathrm{Hb}\right)$. The concentration of oxygen saturation measured by pulse oximetry $\left(\mathrm{SpO}_{2}\right)$ and arterial blood sample $\left(\mathrm{SaO}_{2}\right)$ differs by $\pm 2 \%$ (Nitzan et al. 2014). The accuracy of measurement stated by the manufacturer is within $\pm 3 \%$. All together this can mean up to $6 \%$, which may be a problem when measuring too narrow range of $\mathrm{SpO}_{2}$ (Nitzan et al. 2014, Lakshminrusimha et al. 2015).

The accuracy measurement with pulse oximetry can be negatively affected by a number of factors such as clinical instability of the immature neonate, variable position of the measuring probe ("preductal" position is recommended; e.g. right upper limb), interfering light of the same spectral wavelenght (e.g. phototherapy), $\mathrm{Hb}$ derivates, transfusion of erythrocytes increasing the percentage of $\mathrm{HbA}$ or artifacts caused by physical activity of the child (Lakshminrusimha et al. 2015, Cummings and Polin 2016).

Near-infrared spectroscopy (NIRS) is another frequently used noninvasive technology, measuring the tissue oxygenation of the brain and myocardium. NIRS exploits the relative transparency of biological tissue to near-infrared light (700-1000 nm), and the wavelength dependent absorption characteristics of $\mathrm{Hb}$, which varies with oxygenation. By monitoring the intensity of light passing through the brain at two or more wavelengths, observed changes in attenuation can be converted into changes in cerebral concentration of oxyhemoglobin $\left(\mathrm{HbO}_{2}\right)$ and deoxyhemoglobin $(\mathrm{Hb})$. Depending on the manufactures, the device is able measure the ratio of $\mathrm{HbO}_{2}$ to total $\mathrm{Hb}$ as the tissue oxygenation index (TOI) or the regional cerebral oxygen saturation $\left(\mathrm{rSO}_{2}\right)$ (da Costa et al. 2015). Both, TOI and $\mathrm{rSO}_{2}$, can be used to calculate the fractional tissue oxygen extraction, which by taking varying arterial oxygen saturation measurement into account directly represents the balance between cerebral oxygen supply and cerebral oxygen consumption (Naulaers et al. 2007).

\section{Oxygen saturation during fetal-neonatal transformation}

In utero, the fetus develops at markedly lower $\mathrm{PaO}_{2}$ than after delivery. $\mathrm{PaO}_{2}$ in utero is about 3.4-4.6 $\mathrm{kPa}(25-35 \mathrm{mmHg})$, while after delivery in term infant is between $10.6-12.0 \mathrm{kPa}$ (80 up to $90 \mathrm{mmHg}$ ) (Gao and Raj 2010). The placenta is the principal site of fetal blood gas exchange. Within the placenta, chorionic villi are wrapping with mixed arterial-venous maternal blood with a $\mathrm{PO}_{2}$ around $55 \mathrm{mmHg}(7.3 \mathrm{kPa})$. The exchange of blood gases itself takes place during the flow of blood through the fetal intervillous space $(\mathrm{Wu}$ et al. 2016).

Because $\mathrm{HbF}$ has a higher affinity to oxygen and its extraction from the intervillous space of placenta, and saturation with oxygen at the same $\mathrm{PO}_{2}$ is higher than that of HbA (Vento and Teramo 2013). The provision of an adequate amount of oxygen to the fetus shifts along gestation. Studies performed in human fetuses have shown that before the $12^{\text {th }}$ week of gestation, the median value of intervillous $\mathrm{PO}_{2}$ is around $18-20 \mathrm{mmHg}$ (2.4-2.7 $\mathrm{kPa}$ ) and then steeply raises to median of $60 \mathrm{mmHg}(8 \mathrm{kPa})$ at $14-18$ weeks, and thereafter again decreases slowly to $45-48 \mathrm{mmHg}(6-6.4 \mathrm{kPa})$ at 36 weeks gestation (Kiserud 2005, Schneider 2011).

Birth, even extremely preterm, triggers profound respiratory, circulatory and metabolic changes. Along with increasing lung aeration the pulmonary vascular resistance decreases, right-to-left vascular shunting closes, pulmonary blood flow increases, and required ventilation/perfussion ratio is set. Concurrently, the blood from the right ventricle is redirected to the lungs where it is oxygenated. During the first 5-10 min after birth, $\mathrm{PaO}_{2}$ increases from $40-50 \mathrm{mmHg}(5.3-6.7 \mathrm{kPa})$ to 70-80 $\mathrm{mmHg}(9.3-10.6 \mathrm{kPa}$ ) (Gao and Raj 2010). At the same time, the $\mathrm{SpO}_{2}$ values in the term newborn infants reach up 95-98\%. For premature infants (mean gestational age of 33 weeks) $\mathrm{SpO}_{2}$ will rise up from $60 \%$ to approximately $95 \%$ (Table 1) (Dawson et al. 2010, Torres-Cuevas et al. 2017).

Preterm birth exposes the neonates, including EPNs', to a sudden transition from the oxygen poor to the oxygen rich environment. A sharp increase in oxygen saturation after birth and the immaturity of antioxidant 
systems (enzymatic and non-enzymatic) may contribute to an oxidative stress and production of reactive oxygen species (ROS) (Saugstad 1990, Saugstad 2001, Buonocore et al. 2002, and Escrig et al. 2008). Hitka et al. found the highest content of hydrogen peroxide in exhaled breath condensates of ventilated very preterm neonates within the first hours of life (Fig. 2) (Hitka et al. 2004). This may suggest an association of oxidative stress with extremely preterm delivery as the major cause of severe immaturity of the neonate including his protective antioxidant mechanisms. The immaturity of the defense systems against ROS has two major reasons. First, the antioxidation enzymes are becoming operational during the late gestation. An increase in their activities is taking place at the same time as maturation of pulmonary surfactant production. Concurrently, non-enzymatic antioxidants cross the placenta in increased quantities. Therefore, induction of antioxidants in response to an oxidant challenge does not routinely occur in preterm infants born before $32^{\text {nd }}$ weeks' gestation (Davis and Auten 2010).

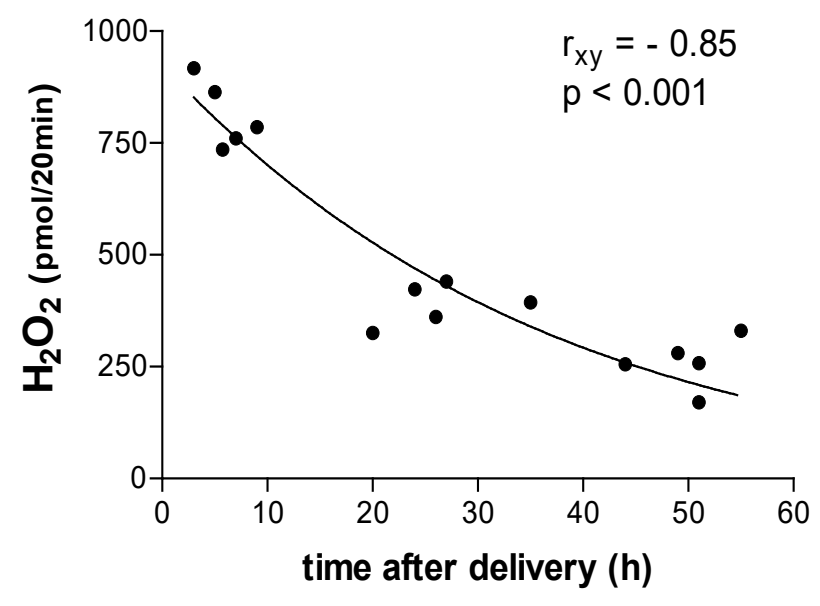

Fig. 2. Correlation between the times elapsed from delivery and $\mathrm{H}_{2} \mathrm{O}_{2}$ production in ventilated very premature neonates (Hitka et al. 2004).

Assessment of $\mathrm{H}_{2} \mathrm{O}_{2}$ concentration on expired breath condensates may provide information about immediate oxidative load in immature lungs. High production of $\mathrm{H}_{2} \mathrm{O}_{2}$ shortly after birth may reflect transition from fetal to neonatal oxygenation. Subsequent decrease of its values in expired breath condensates seems to be caused mainly by its reduced production.

Table 1. Spontaneous $\mathrm{SpO}_{2}$ changes in term and preterm neonates after birth.

\begin{tabular}{lccc}
\hline Term neonates (time) & $\mathbf{S p O}_{\mathbf{2}}$ (range) & Preterms (time) & SpO $_{2}$ (range) \\
\hline 1 min & $68 \%(60-77)$ & $1 \mathrm{~min}$ & $62 \%(47-72)$ \\
$2 \mathrm{~min}$ & $76 \%(65-84)$ & $2 \mathrm{~min}$ & $68 \%(58-78)$ \\
$3 \mathrm{~min}$ & $81 \%(71-90)$ & $3 \mathrm{~min}$ & $76 \%(67-83)$ \\
$4 \mathrm{~min}$ & $88 \%(78-94)$ & $4 \min$ & $81 \%(72-88)$ \\
$5 \mathrm{~min}$ & $92 \%(83-96)$ & $5 \mathrm{~min}$ & $86 \%(80-92)$ \\
$10 \mathrm{~min}$ & $97 \%(94-98)$ & $10 \min$ & $94 \%(91-97)$ \\
\hline
\end{tabular}

(Data according to Kamlin et al. 2006, Dawson et al. 2010, Nuntnarumit et al. 2010)

\section{Target range of $\mathrm{SpO}_{2}$ in extremely premature neonates}

Searching for target range of oxygen saturation defining normoxemia in premature infants has been taking place since the late 1940s. Methods assessing or estimating the oxygenation of EPNs', incl. pulse oximetry, described in the previous section, only partially extended our horizon of knowing the optimal target range of $\mathrm{SaO}_{2} / \mathrm{SpO}_{2}$ in these babies. Therefore the question of what concentration of oxygen is "optimal" to them remains unanswered (Cummings and Polin 2016, Askie et al. 2017).

Pretty recently, the five major international randomized studies (American SUPPORT, Canadian COT, and UK-Australian-New Zealand BOOST II) evaluating the effects of two pre-specified $\mathrm{SpO}_{2}$ targets, i.e. low (85-89 \%) vs. high (91-95\%), in EPNs' have been completed and their findings published (Carlo et al. 2010, Vaucher et al. 2012, Schmidt et al. 2013, Stenson et al. 2013, Tarnow-Mordi et al. 2016). These trials have been designed together so that EPNs' were randomly assigned to the one of two preselected $\mathrm{SpO}_{2}$ ranges. Their primary outcome was a composite of death or disability at 18-24 months' corrected age, the secondary outcome included occurrence of intraventricular hemorrhage (IVH), necrotizing enterocolitis (NEC), bronchopulmonary dysplasia (BPD), and retinopathy of prematurity (ROP). Death before discharge was a pre-specified secondary outcome only in the Boost II studies (Manja et al. 2015, Cummings and Lakshminrusimha 2017). Data from over 5,000 tiniest neonates were collected and processed. Their analyses have shown that a higher target range $\mathrm{SpO}_{2}$ (91-95\%) 
Table 2. Some of frequently discussed recommendations to the oxygen therapy of very and extremely preterm newborns.

1) Stabilization after delivery:

- $\quad$ Start with $\mathrm{FiO}_{2}$ 0.21-0.30;

- Later - titrate $\mathrm{FiO}_{2}$ according to the clinical status and actual $\mathrm{SaO}_{2} / \mathrm{SpO}_{2}$ values.

2) Frequently discussed target ranges of $\mathrm{SpO}_{2}$ :

- Higher and narrower target range of 91-94\%;

- $\quad$ Lower and wider target range 88-94\% [B2].

3) The wider range of $\mathrm{SpO}_{2}$ - easier maintain $\mathrm{SpO}_{2}$ values within desired range and prevent exceeding of alarm settings [C2];

- $\quad$ Setting alarm limits: - lower between 85-87\%, upper between 94-96 \% [D2].

4) Repeatedly exceeded $\mathrm{SpO}_{2}$ target limits indicate examination of the $\mathrm{PaO}_{2}$ and $\mathrm{SaO}_{2}$ from arterial blood sample.

5) Hemoglobin $(\mathrm{Hb})$ concentrations in extremely premature neonates with respiratory support and oxygen when considering transfusion of erythrocytes:

- $\quad$ during the $1^{\text {st }}$ week of birth: Hb $115 \mathrm{~g} / \mathrm{l}$ (Hct 0.35 );

- $\quad$ until 2 weeks after delivery: Hb $110 \mathrm{~g} / \mathrm{l}$ (Hct 0.30);

- $\quad$ after the $2^{\text {nd }}$ week of delivery: Hb $85 \mathrm{~g} / \mathrm{l}$ (Hct 0.25) [C2].

Grading according to the GRADE system (Guyatt HG et al. 2011)

was associated with lower mortality at the age of 36 weeks after conception (i.e. before discharge), but also with increased occurrence of severe ROP. Later metaanalysis didn't confirm the increased incidence of ROP as significant (Cummings and Lakshminrusimha 2017). On the other hand, the lower $\mathrm{SpO}_{2}$ range (85-89\%) was found to be associated with an increased mortality at 36 post-conception weeks' and more frequent NEC (necrotizing enterocolitis) (Stenson 2016).

The conclusions of studies attracted considerable attention and became the subjects of systematic analyses and reviews of the primary and secondary outcomes, along with the methods used, the level of evidence quality and the interpretation of findings (Sola et al. 2014, Lakshminrusimha et al. 2015, Manja et al. 2015, Cummings and Lakshminrusimha 2017, Askie et al. 2017). According to the reviewers' view, the methods and interventions used in the reviewed trials had physiologic, technical, and implementation shortcomings that raised the questions about validity and applicability of acquired findings in the practice. The objections mainly concerned the age heterogeneity of neonates at enrollment, comorbidities between trials and change in oximeter algorithm midway through three trials (Lakshminrusimha et al. 2015, Manja et al. 2017).

Concerns raised mainly conclusions of SUPPORT II study on the causal link between restricted $\mathrm{SpO}_{2}$ target range (85-89\%) and increased institutional mortality (i.e. before discharge home) or of increased incidence of severe ROP (stage $\geq 3$ ) in case of liberal $\mathrm{SpO}_{2}$ range (90-95\%) (Cummings and Lakshminrusimha
2017). Manja et al. pointed out that although EPNs' with a liberal (higher) oxygen target had significantly lower mortality before discharge, the quality of evidence for this finding is low (Manja et al. 2015). In addition, the last two systematic reviews have come to conclusions, that restrictive vs. liberal $\mathrm{SpO}_{2}$ had no significant effect on the primary composite outcome of death or major disability or on the major disability alone (Askie et al. 2017, Manja et al. 2017).

\section{Interim concluding remarks}

Currently, two concepts of the optimal $\mathrm{SpO}_{2}$ target range - narrow (90-94\%) and wider (88-94\%) are being discussed. However, each carries the risk of either hypoxic or hyperoxic overlaps and is thus unacceptable (Sola et al. 2014, Sweet et al. 2017). (Table 2) Manley et al. have recently reported that changing the $\mathrm{SpO}_{2}$ target range from $88-92 \%$ to $91-95 \%$ led to a twofold increase in the incidence of severe ROP (Manley et al. 2016). In the report of 2016, American Academy of Pediatrics states that the ideal physiologic range of $\mathrm{SpO}_{2}$ means a compromise between the negative consequences caused either by hyperoxemia or hypoxemia, but such ideal $\mathrm{SpO}_{2}$ range for EPNs' remains unknown (Cummings and Polin 2016). In addition, any premature neonates, including those born extremely preterm, have probably individually different susceptibility or resilience to an impairment caused either by hypoxia or hyperoxia (Synnes and Miller 2015). Factors as corrected gestational age, postnatal age, growth, perinatal and neonatal comorbidity, extrinsic 
factors, all that may have impact on the severity and extent of hypoxic or oxidative impairment. It is unlikely that a single narrow $\mathrm{SpO}_{2}$ range can be found that would be safe for all extremely premature neonates. Advances in avoiding the oxygen related impairments either for too little or too much of oxygen depends on the better understanding the pathophysiologic processes related organ injury, especially in the category of EPNs' (Cummings and Lakshminrusimha 2017). Despite all efforts, considerable uncertainty persists about the desired target range of $\mathrm{SpO}_{2}$ in EPNs'. Further studies should focus on studying newer methods of assessing oxygenation strategies to limit hypoxemia $\left(<85 \% \mathrm{SpO}_{2}\right)$ and hyperoxemia $\left(>95 \% \mathrm{SpO}_{2}\right)$. The latest reports on clinical experience with automated closed-loop of $\mathrm{FiO}_{2}$ control of oxygen saturation look promising (van Zanten et al. 2017, van den Heuvel et al. 2018).

\section{Conflict of Interest}

There is no conflict of interest.

\section{References}

AMERICAN ACADEMY OF PEDIATRICS, AMERICAN COLLEGE OF OBSTETRICIANS AND GYNECOLOGISTS COG, MARCH OF DIMES BIRTH DEFECTS FOUNDATION: Guidelines for Perinatal Care, Ed 6 Washington, American Academy of Pediatrics and American College of Obstetricians and Gynecologists, 2007.

ARIKAN GM, HAEUSLER MC, HAAS J, SCHOLZ H: Does the hemoglobin concentration in fetal blood interfere with the accuracy of fetal reflection pulse oximetry? Fetal Diagn Ther 13: 236-240, 1998.

ASKIE LM, DARLOW BA, DAVIS PG, FINER N, STENSON B, VENTO M, WHYTE R: Effects of targeting lower versus higher arterial oxygen saturations on death or disability in preterm infants. Cochrane Database Syst Rev 4: CD011190, 2017. doi: 10.1002/14651858.CD011190.pub2.

BUONOCORE G, PERRONE S, LONGINI M, VEZZOSI P, MARZOCCHI B, PAFFETTI P, BRACCI R. Oxidative stress in preterm neonates at birth and on the seventh day of life. Pediatr Res 52: 46-49, 2002.

CAMPBELL K: Intensive oxygen therapy as a possible cause of retrolental fibroplasia: a clinical approach. Med $J$ Aust 2: 48-50, 1951.

CARLO WA, FINER NN, WALSH MC, RICH W, GANTZ MG, LAPTOOK AR, YODER BA, FAIX RG, DAS A, POOLE WK, SCHIBLER K, NEWMAN NS, AMBALAVANAN N, FRANTZ ID 3RD, PIAZZA AJ, SÁNCHEZ PJ, MORRIS BH, LAROIA N, PHELPS DL, POINDEXTER BB, COTTEN CM, VAN MEURS KP, DUARA S, NARENDRAN V, SOOD BG, O'SHEA TM, BELL EF, EHRENKRANZ RA, WATTERBERG KL, HIGGINS RD, SUPPORT Study Group of the Eunice Kennedy Shriver NICHD Neonatal Research Network: Target ranges of oxygen saturation in extremely preterm infants. $N$ Engl J Med 362: 1959-1969, 2010. doi: 10.1056/NEJMoa0911781

CHAN ED, CHAN MM, CHAN MM: Pulse oximetry: understanding its basic principles facilitating appreciation of its limitations. Respir Med 107: 789-799, 2013.

CROSS V: The problem of retrolental fibroplasia in the city of Birmingham. Trans Ophthalmol Soc UK 71: 609-612, 1951.

CUMMINGS JJ, POLIN RA, COMMITTEE ON FETUS AND NEWBORN: Oxygen Targeting in Extremely Low Birth Weight Infants. Pediatrics 138: e20161576, 2016.

CUMMINGS JJ, LAKSHMINRUSIMHA S: Oxygen saturation targeting by pulse oximetry in the extremely low gestational are neonate: a quixotic quest. Curr Opin Pediatr 29: 153-158, 2017.

DA COSTA CS, GREISEN G, AUSTIN T: Is near-infrared spectroscopy clinically useful in the preterm infant? Arch Dis Child Fetal Neonatal Ed 2015; 0:F1F4. doi:10.1136/archdischild -2014-307919.

DAVIS JM, AUTEN RL: Maturation of the antioxidant system and the effects on preterm birth. Semin Fetal Neonatal Med 15: 191-195, 2010.

DAWSON JA, KAMLIN CO, VENTO M, WONG C, COLE TJ, DONATH SM, DAVIS PG, ESCRIG R, ARRUZA L, IZQUIERDO I, VILLAR G, SAENZ P, GIMENO A, MORO M, VENTO M: Achievement of Targeted Saturation Values in Extremely Low Gestational Age Neonates Resuscitated With Low or High Oxygen Concentrations: A Prospective, Randomized Trial. Pediatrics 121: 875- 881, 2008.

GAO Y, RAJ JU: Regulation of the pulmonary circulation in the fetus and newborn. Physiol Rev 90: 1291-1335, 2010. 
GLASS C, COSTARINO AT, STAYER SA, BRETT C, CLADIS F, DAVIS PJ: Outcomes for Extremely Premature Infants. Anesth Analg 120: 1337-1351, 2018.

GLICKSTEIN JS: Cardiology. In: Fetal \& Neonatal Secrets. POLIN RA, SPITZER AR (eds). Mosby Elsevier, 2007, pp 80-90.

GUYATT GH, OXMAN AD, VIST G, KUNZ R, BROZEK J, ALONSO-COELLO P, MONTORI V, AKL EA, DJULBEGOVIC B, FALCK-YTTER Y, NORRIS SL, WILLIAMS JW JR, ATKINS D, MEERPOHL J, SCHÜNEMANN HJ: GRADE guidelines: 4. Rating the quality of evidence-study limitations (risk of bias). $J$ Clin Epidemiol 64: 407-415, 2011.

HITKA P, ČERNÝ M, VÍZEK M, WILHELM J, ZOBAN P: Assessment of Exhaled Gases in the Ventilated Preterm Infants. Physiol Res 53: 561-564, 2004.

KAMLIN CO, O'DONNELL CP, DAVIS PG, MORLEY CJ: Oxygen saturation in healthy infants immediately after birth. J Pediatr 148: 585-589, 2006.

KISERUD T: Physiology of the fetal circulation. Semin Fetal Neonatal Med 10: 493-503, 2005.

LAKSHMINRUSIMHA S, MANJA V, MATHEW B, SURESH K: Oxygen Targeting on Preterm Infants: A Physiologic Interpretation. J Perinatol 35: 8-15, 2015.

MANJA V, LAKSHMINRUSIMHA S, COOK DJ: Oxygen Saturation Target Range for Extremely Preterm Infants: A Systematic Review and Meta-analysis. JAMA Pediatr 169: 332-340, 2015.

MANJA V, SAUGSTAD OD, LAKSHMINRUSIMHA S: Oxygen Saturation Targets in Preterm Infants and Outcomes at 18-24 Months: A Systematic Review. Pediatrics 139: e20161609, 2017.

MANLEY BJ, KUSCHEL CA, ELDER JE, DOYLE LW, DAVIS PG: Higher rates of retinopathy of prematurity after increasing oxygen saturation targets for very preterm infants: experience in a single center. $J$ Pediatr 168: 242-244, 2016.

MORLEY CJ: Defining the reference range for oxygen saturation for infants after birth. Pediatrics 125: e1340-1347, 2010.

NAULAERS G, MEYNS B, MISEREZ M, LEUNENS V, VAN HUFFEL S, CASANER P, WEINDLING M, DEVLIEGER H: Use of tissue oxygenation index and fractional tissue oxygen extraction as noninvasive parameters for cerebral oxygenation. A validation in piglets. Neonatology 92: 120-126, 2007.

NITZAN M, ROMEM A, KOPPEL R: Pulse oximetry: fundamentals and technology. Med Devices (Auckl) 7: 231-239, 2014.

NUNTNARUMIT P, ROJNUEANGNIT K, TANGNOO A: Oxygen saturation trends in preterm infants during the first 15 min after birth. $J$ Perinatol 30: 399-402, 2010.

RICHARDSON DK and EICHENWALD EC: Blood Gas Monitoring and Pulmonary Function Test. In: Manual of Neonatal Care. CLOHERTY JP, STARK AR (eds), Lippincott-Raven, Philadelphia, 1998, pp 353-358.

SAUGSTAD OD: 50Years Ago in the Journal of Pediatrics: Arterial Oxygen Tension in Premature Infants. $J$ Pediatr 176: 61, 2016. doi: 10.1016/j.peds.2016.03.052.

SAUGSTAD OD: Oxygen toxicity in the neonatal period. Acta Paediatr Scand 79: 881-892, 1990.

SAUGSTAD OD: Update on oxygen radical disease in neonatology. Curr Opin Obstet Gynecol 13: 147-153, 2001.

SCHMIDT B, WHYTE RK, ASZTALOS EV, MODDEMANN D, POETS C, RABI Y, SOLIMANO A, ROBERTS RS; Canadian Oxygen Trial (COT) Group: Effects of targeting higher vs lower arterial oxygen saturations on death or disability in extremely preterm infants: a randomized clinical trial. JAMA 309: 2111-2120, 2013.

SCHNEIDER H: Oxygenation of fetal-placental unit in human. Respir Physiol Neurobiol 178: 51-58, 2011.

SOLA A, GOLOMBEK SG, BUENO MT, LEMUS-VARELA L, ZULUAGA C, DOMINGUEZ F, BAQUERO H, YOUNG SARMIENTO AE, NATTA D, RODRIGEZ PEREZ J, DEULOFEUT R, QUIROGA A, FLORES GL, MORGUES M, PÉREZ AG, VAN OVERMEIRE B, VAN BEL F: Safe oxygen saturation targeting and monitoring in preterm infants: can we avoid hypoxia and hyperoxia? Acta Paediatr 103: 1009-1018, 2014. doi: 10.1111/apa.12692. 
STENSON BJ, TARNOW-MORDI WO, DARLOW BA, SIMES J, JUSZCZAK E, ASKIE L, BATTIN M, BOWLER U, BROADBENT R, CAIRNS P, DAVIS PG, DESHPANDE S, DONOGHOE M, DOYLE L, FLECK BW, GHADGE A, HAGUE W, HALLIDAY HL, HEWSON M, KING A, KIRBY A, MARLOW N, MEYER M, MORLEY C, SIMMER K, TIN W, WARDLE SP, BROCKLEHURST P; BOOST II United Kingdom Collaborative Group; BOOST II Australia Collaborative Group; BOOST II New Zeeland Collaborative Group: Oxygen saturation and outcomes in preterm infants. N Engl J Med 368: 2094-2104, 2013.

STENSON BJ: Oxygen saturation targets for extremely preterm infants after the NeOProM Trials. Neonatology 109: 352-358, 2016.

SWEET D, BEVILACQUA G, CARNIELLI V, GREISEN G, PLAVKA R, SAUGSTAD OD, SIMEONI U, SPEER CP, WALLS-I-SOLER A, HALLIDAY H: Working Group on Prematurity of the World Association of Perinatal Medicine; European Association of Perinatal Medicine: European consensus guidelines on the management of neonatal respiratory distress syndrome. J Perinat Med 35: 175-186, 2007.

SWEET DG, CARNIELLI V, GREISEN G, HALLMAN M, OZEK E, PLAVKA R, SAUGSTAD OD, SIMEONI U, SPEER CP, VENTO M, VISSER GHA, HALLIDAY HL: European Consensus Guidelines on the Management of Neonatal Respiratory Distress Syndrome in Preterm Infants - 2016 Update. Neonatology 111: 107-125, 2017.

SYNNES A, MILLER SP: Oxygen therapy for preterm neonates: the elusive optimal target. JAMA Pediatr 169: 311-313, 2015.

TARNOW-MORDI W, STENSON B, KIRBY A, JUSZCZAK E, DONOGHOE M, DESHPANDE S, MORLEY C, KING A, DOYLE LW, FLECK BW, DAVIS PG, HALLIDAY HL, HAGUE W, CAIRNS P, DARLOW BA, FIELDER AR, GEBSKI V, MARLOW N, SIMMER K, TIN W, GHADGE A, WILLIAMS C, KEECH A, WARDLE SP, KECSKES Z, KLUCKOW M, GOLE G, EVANS N, MALCOLM G, LUIG M, WRIGHT I, STACK J, TAN K, PRITCHARD M, GRAY PH, MORRIS S, HEADLEY B, DARGAVILLE P, SIMES RJ, BROCKLEHURST P; BOOST II Australia and United Kingdom Collaborative Groups: Outcomes of two trials of oxygen-saturation targets in preterm infants. $N$ Engl J Med 374: 749-760, 2016.

TERRY TL: Fibroblastic Overgrowth of Persistent Tunica Vasculosa Lentis in Infants Born Prematurely: II Report of Cases - Clinical Aspects. Trans Am Ophthalmol Soc 40: 262-284, 1942.

TORRES-CUEVAS I, PARRA-LORCA A, SANCHEZ-ILLANA A, NUNEZ-RAMIRO A, KULIGOWSKI J, CHAFER-PERICAS C, CERNADA M, ESCOBAR J, VENTO M: Oxygen and oxidative stress in the perinatal period. Redox Biol 12: 674-681, 2017.

VAN DEN HEUVEL MEN, VAN ZANTEN HA, BACHMAN TE, TE PAS AB, ANTON H, VAN KAAM AH, ONLAND W: Optimal Target Range of Closed-Loop Inspired Oxygen Support in Preterm Infants: A Randomized Cross-over Study. J Pediatr 197: 36-41, 2018.

VAN ZANTEN HA, KUYPERS KLAM, STENSON BJ, BACHMAN TE, PAUWS SC, TE PAS AB: The effect of implementing an automated oxygen control on oxygen saturation in preterm infants. Arch Dis Child Fetal Neonatal Ed 102: F395-F399, 2017.

VAUCHER YE, PERALTA-CARCELEN M, FINNER NN, CARLO WA, GANTZ MG, WALSH MC, LAPTOOK AR, YODER BA, FAIX RG, DAS A, SCHIBLER K, RICH W, NEWMAN NS, VOHR BR, YOLTON K, HEYNE RJ, WILSON-COSTELLO DE, EVANS PW, GOLDSTEIN RF, ACARREGUI MJ, ADAMSCHAPMAN I, PAPPAS A, HINTZ SR, POINDEXTER B, DUSICK AM, MCGOWAN EC, EHRENKRANZ RA, BODNAR A, BAUER CR, FULLER J, O'SHEA TM, MYERS GJ, HIGGINS RD; SUPPORT Study Group of the Eunice Kennedy Shriver NICHD Neonatal Research Network: Neurodevelopmental outcomes in the early CPAP and pulse oximetry trial. N Engl J Med 367: 2495-2504, 2012.

VENTO M, TERAMO K: Evaluating the fetus at risk for cardiopulmonary compromise. Semin Fetal Neonatal Med 18: 324-329, 2013.

WOLFBERG AJ, DU PLESSIS AJ: Near-infrared spectroscopy in the fetus and neonate. Clin Perinatol 33: 707-728, 2006.

WU TW, AZHIBEKOV T, SERI I: Transitional Hemodynamics in Preterm Neonates: Clinical Relevance. Pediatr Neonatol 57: 7-18, 2016. 